\title{
Intertwine between Technology and Diplomacy: Indonesian E-Diplomacy in Achieving Palestinian Independence
}

\author{
D Yulianti ${ }^{1}$, R W S Sumadinata ${ }^{2}$, T N Mursitama ${ }^{3}$ \\ ${ }^{1,2}$ Department of International Relations, Universitas Padjadjaran, Sumedang, Indonesia \\ ${ }^{3}$ Faculty of Humanities, Universitas Bina Nusantara, Jakarta, Indonesia \\ 1dinay3007@gmail.com
}

\begin{abstract}
The advancement of technology has been very useful for many aspects of human life including diplomacy. This paper addresses how twitter as an example of technology intertwine with diplomacy particularly Indonesia e-diplomacy towards Palestinian issue. The Palestinian problem occupies the focus of Indonesia's foreign policy, as stated by the country's foreign minister, Retno Marsudi, "Palestine will always be in theheart of Indonesia's foreign policy". Along with the increasing use of social media as a tool of diplomacy by world leaders, this article examines how intense Indonesian government utilize the proPalestinian e-diplomacy. This study uses an open source program to filter, analyze and visualize the Tweet of Indonesian people using the word 'Palestina' and conduct manual observations of 3 particular accounts: @ Menlu_RI, @Kemlu_RI, and @Jokowi. The data interpretation follows the discourse analysis procedure. This study suggest Indonesian government has not enhance its power in diplomacy using the social media platform, especially Twitter, to influence the policies and attitudes of other governments in the issue of Palestine.
\end{abstract}

Keywords: Indonesian, Palestine, Twitter

\section{INTRODUCTION}

The Palestinian-Israeli conflict is a major problem in the Middle East that has not been resolved after 70 years. Geographically, Gaza and Jakarta are more than 8700 kilometers apart, yet the Palestine question is deemed hight priority in Indonesia's foreign policy. On the 11th of May 2018, President Joko Widodo condemned the move of United State's of America's embassy to Jerusalem by stating, "We, together with Indonesian people, will fight alongside Palestinians and Palestine will always be within the breaths of Indonesia's diplomacy" [1].

Indonesian support to the Palestinians has begun long before Indonesia declared its independence on the 17th of August 1945. In 1938, Indonesian's Islamic scholars that are united in an organization "Nahdlatul Ulama" (NU) raised aid for Palestinian people who were taking up arms against the British Mandate. In that three-year war, British troops committed numerous brutal attacks against civilians resulting in many dead or wounded [2]. The NU leaders then ordered all NU branches to "spread out boars of charity for orphans and widows in Palestine at various assemblies during the month of Rajab" [3].

Following Indonesia's declaration of its independence in 1945, the newborn country needed diplomatic recognition from other countries worldwide. According to M. Zein Hassan, Indonesian diplomat who was intensely and directly involved in the effort to seek diplomatic 
acknowledgement from Middle Eastern countries, Lajnatud Difa'i 'an Indonesia or Indonesian Defense Committee was formed on 16th of October 1945. The conference to establish this commitee was held in Cairo and attended by a number of important figures in the Arab World such as the Chairman of the Islamic Youth Association (who was then elected as the Chairman of the Indonesian Defense Committee), General Saleh Harb Pasya; Secretary General of the Arab League, Abdulrahman Azzam Pasya, Chairman of the Palestinian Committee, Muhammad Ali Taher; representatives of the Muslim Brotherhood, Taufik Syawi; the Tunisian representative, Habib Bourguiba (later became the President of Tunisia); as well as some other envoys such as Foudeil Wartalani from Algeria, Asad Salmaniyeh from Lebanon, Mirza Miski Beg from Iran, and the Chairman of the Chinese Students Union in Cairo. The outcome of the meeting is a resolution to support the Republic of Indonesia and calls for all countries, especially Arab and Islamic countries to recognize the Republic of Indonesia [4].

Finally, on the 22nd of March 1946, the Egyptian government officially recognized Indonesia's independenceand sovereignty. Not long after, on the 18th of November 1946, the Council of Foreign Ministers of the Arab League instructed its member states to follow suit (Hassan, 1980: 184). Until December 1949 when Netherland finally acknowledge Indonesia's independence and sovereignty de facto and de jure, preceding de facto and de jure recognition had come from Egypt, Saudi Arabia, Syria, Yemen, Iraq, and Afghanistan; while India and Pakistan only gave de facto recognition [4].

Thus it appears that ever since its establishment, the Republic of Indonesia has been having strong relations with the Arab countries. This serves as one of the main backgrounds for Indonesia's foreign policy that stays firmly on Palestine's side and refuses to open diplomatic ties with Israel since it was established in 1948.

Indonesia contributes actively in pro-Palestine diplomatic efforts in various international forums.Parallel to the growing use of social media as a diplomatic apparatus of the countries worldwide, this paper aims to observe how Indonesian government, especially Ministry of Foreign Affairs, exploit the digital network in its diplomatic attempt in achieving Palestinian independence. We hope this study contributes to a deeper understanding in the study of ediplomacy, especially the usage of social media in gathering support toward Palestinian independence. The first part of this paper describes the role of Twitte in diplomacy. The second part analyzes the case studies of the Twitter usage by Indonesian goverment in proPalestine diplomacy. The last part proposes the conclusion of this paper.

\section{METHOD}

Data was gathered using an open source program to filter, analyze and visualize the tweet of Indonesian people using the word "Palestina". The authors also conducted manual observations of 3 particular accounts: @ Menlu_RI, @Kemlu_RI, and @Jokowi. The observation periode was from the 14th to 15th of May 2018, around the time of inauguration for US embassy in Jerusalem, with the assumption that public attention on the Palestinian issue would be quite high. The data interpretation follows the discourse analysis procedure.

\section{RESULT AND DISCUSSION}

\subsection{Twitter and its Role in Diplomacy}

Diplomacy is a major tool for a country to achieve its foreign policy objectives [5] and the political process for fostering foreign policy and aimed at influencing the policies and attitudes 
of other governments [6]. Diplomacy is also perceived as a soft way for a country in enhacing its power in influencing other countries [7]. In the past, diplomatic efforts were made in elite circles and public could not following the process in the real time. However, along with the revolution in the field of information and technology, the world's population communicate much more easily, so that information exchange happens very quickly. A bombing in Gaza, will be known by people around the world in just minutes.

This development brought about changes in the ways of diplomacy of world leaders. The governments convey its foreign policy to the world community quickly and the leaders communicate with each other can be followed by the world community in the real time. Messages delivered by a government through the internet, especially social media, can spread quickly and reach out to the wider public, both domestic and foreign. As Harder wrote, Twitter makes "foreign policy less foreign to the public' and moves 'foreign policy closer to the people" [8].

Especially for the case of Palestine, a country that has not been independent, social media has played an important role in helping the Palestinian goverment to convey her foreign policy and reaching the broader public, including governments of various countries that have no diplomatic relations with her. The Palestinian official actively uses social media, such as @nadplo and @PalestinaUSA or Facebook account Embassy of Palestine-Tokyo and Mission of Palestine-Denmark. According to digital diplomacy expert, Ilan Manor, there are three main focuses of the Palestinian digital diplomacy strategy, that is "demonstrating international recognition of Palestinian sovereignty, seeking digital recognition of Palestine and presenting Palestine as a 'State in The Making"' [9].

A global study titled "Twiplomacy" conducted by PR companies, Burson-Marsteller [10] found that Twitter is the most widely used social media of world leaders and governmental institutions, while Facebook and Instagram are ranked in second and third. As many as 77.7\% world leaders (presidents, prime ministers, and foreign ministers) in 153 countries have Twitter accounts.

Twitter has changed the language pattern among world leaders. Diplomatic language has a low tone and a special pattern that gives space for the opposite to keep his self-esteem, and protect the messenger from bad risks due to incorrect use of the diplomatic language. The particular pattern of diplomatic language is ambiguous so that both parties who interact have the freedom to then disprove without losing his/her face [11].

But with a capacity of only 280 characters, the sentence of Tweet-diplomacy becomes shorter and more straightforward. As a result, traditional diplomatic ethics is often violated. It becomes discontinuous on e-diplomacy using Twitter. Instead of making world leader closer, Twitter can exacerbate the conflict. The bold example of this discontent is the capslock-tweet of US President Trump (@realDonaldTrump) on July 22, 2018:

To Iranian President Rouhani: NEVER, EVER THREATEN THE UNITED STATES AGAIN OR YOU WILL SUFFER CONSEQUENCES THE LIKES OF WHICH FEW THROUGHOUT HISTORY HAVE EVER SUFFERED BEFORE. WE ARE NO LONGER A COUNTRY THAT WILL STAND FOR YOUR DEMENTED WORDS OF VIOLENCE \& DEATH. BE CAUTIOUS!

Iranian Foreign Minister, Javad Zarif ( @ Jzarif) tweeted back on July 24, 2018:

COLOR US UNIMPRESSED: The world heard even harsher bluster a few months ago. And Iranians have heard them - albeit more civilized ones-for 40 yrs. We've been around 
for millennia \& seen fall of empires, incl our own, which lasted more than the life of some countries. BE CAUTIOUS!

But Twitter is also considered as important aspect in the successful of the 2015 nuclear deal as the US and Iranian Foreign Ministers communicate freely; cut through the diplomatic impasse between the two countries since 1980 [12].

\subsection{Twitter Utilization by Indonesian Government in Pro-Palestine Diplomacy}

Twitter is a very popular social media platform in Indonesia and the country comes up as the fifth-largest country in the world regarding Twitter users (Jakarta Globe, 2017).According to the Twiplomacy study of 2013, US President @BarackObama was the most followed world leader on Twitter while the President of Indonesia @SBYudhoyono was one of the top 10 most followed world leaders. In a similar study in 2017, Pope Francis of Vatican @ Pontifex is ranked in first position with over 33.7 million followers; and President of Indonesia, now is Mr. Joko Widodo@Jokowi, completed the list of the top 10 most followed world leaders with more than 7.4 million followers [13].

Thus, for the Indonesian government, the use of Twitter as a medium of diplomacy is very potential because of its very wide coverage. Assuming that "Palestine will always be in the breath of Indonesia's diplomacy"and "Palestine is in the heart of Indonesian foreign policy" [14] we expect the intensive use of social media by the government on this issue.

The authors figured out the Twitter conversation with the keyword "Palestina" on 14th to 15th of May 2018, the day when the US opening her embassy in Jerusalem and the day after. Byusing an open source program to filter and visualize the certain Tweet, we found 45378 Tweets or 300495 Tweets with retweets that contain the word "Palestina" from all around the world.

The number of accounts which tweeted "Palestina" from Indonesia are 1240 and @Menlu_RI is ranked in 8th most retweet account, as seen in the table below.

\begin{tabular}{|c|c|}
\hline Tweet tertentu oleh Akun & Frekuensi diretweet \\
\hline Row Labels & I Sum of retweets \\
\hline Ehttps://twitter.com/AgusMagelangan/status/996034908953837570 & 241 \\
\hline AgusMagelangan & 241 \\
\hline - https://twitter.com/sahabatalaqsha/status/995993796092481537 & 224 \\
\hline sahabatalaqsha & 224 \\
\hline Ehttps://twitter.com/Hayyivira_Rach/status/996003410674499586 & 182 \\
\hline Hayyivira_Rach & 182 \\
\hline - https://twitter.com/detikcom/status/996015663385726976 & 165 \\
\hline detikcom & 165 \\
\hline Ehttps://twitter.com/Husen Jafar/status/996069982071996416 & 153 \\
\hline Husen_Jafar & 153 \\
\hline - https://twitter.com/detikcom/status/996051467592122371 & 136 \\
\hline detikcom & 136 \\
\hline - https://twitter.com/sahabatalaqsha/status/995964211132944384 & 119 \\
\hline sahabatalaqsha & 119 \\
\hline - https://twitter.com/Menlu RI/status/996036280176721922 & 103 \\
\hline Menlu_RI & 103 \\
\hline
\end{tabular}

Figure 1.The Number of Accounts which Tweeted "Palestina" from Indonesia.

If the search is narrowed, e.g. with the keyword "Palestina" and exact_phrase "Indonesia", there are 122 Tweets or 473 with retweets, as illustrated in the following graphic. 


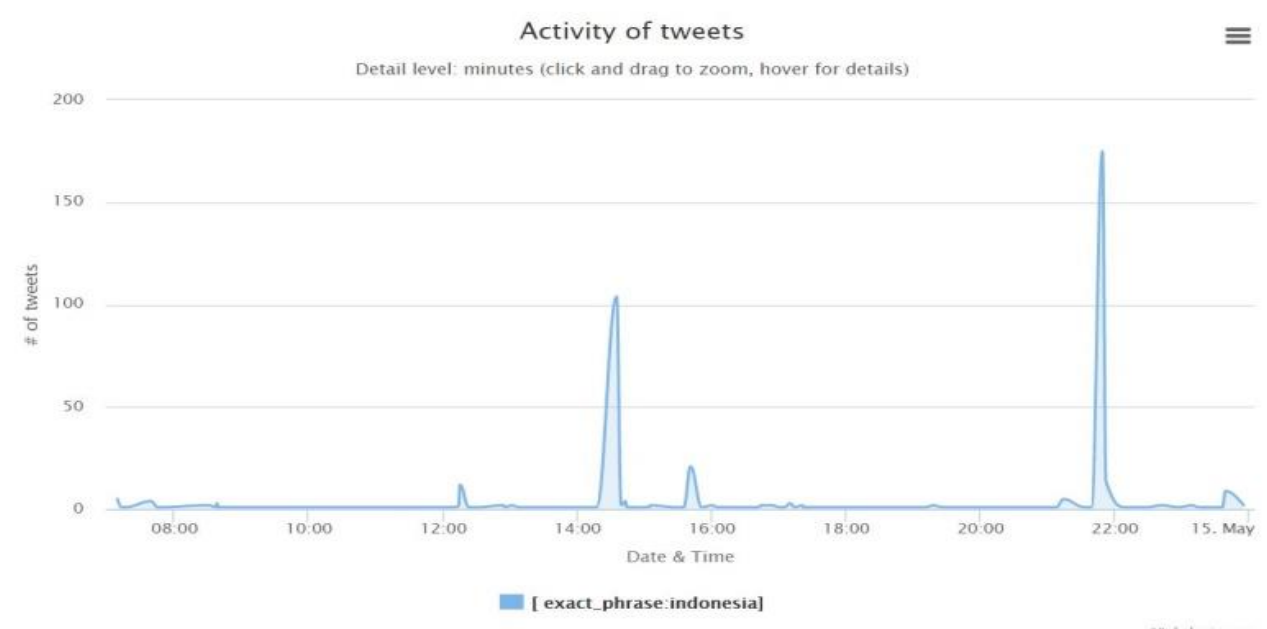

Figure 2. The Result of Twitter Search with the Keyword "Palestina" and "Indonesia".

Tweet with the highest response seen in the graphic was tweeted on 14th of May at 9:49 pm from @hasmi_bakhtiar, which was retweeted 174 times and got 247 likes and 24 comments. It stated [translation], "USA moved its embassy to Jerusalem, Erdogan asked [his] ambassador to go back to Ankara. In the name of Indonesian constitution, Mr @ Jokowi please consider to follow Turkey's action. The USA and Israel both have committed savagery towards Palestinian people."

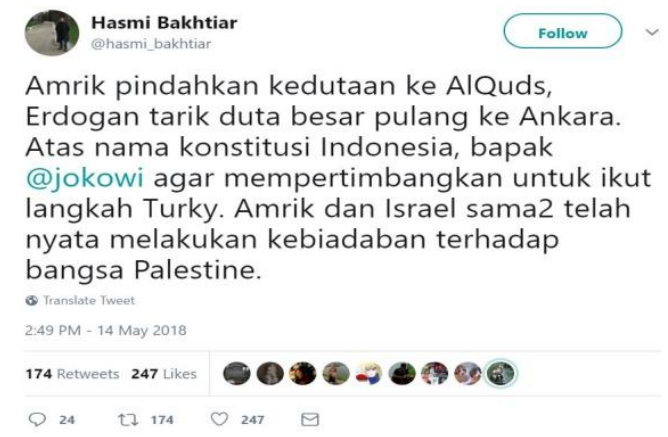

Figure 3.Tweet with the Highest Response.

The qualitative observation to this Tweet are as follows.

1. The account owner does not know that Indonesia does not have diplomatic relations with Israel so the country can not conduct a similar diplomatic response with Turkey.

2. Most of comments on this tweet expressed disappointment and even condemnation of President Jokowi while praising President Erdogan.

3. No government account (@Kemlu_RI or@Menlu_RI) provided explanatory or clarification comments on this Tweet. Some public accounts did informed that Indonesia has no diplomatic relations with Israel. 
Qualitative observation of these 122 Tweets found that there were several types of response related to the inauguration of the US Embassy in Jerusalem:

1. Full Palestinian support without linking the issue to domestic issues or conspiracy theories (58 Tweets).

2. Questioning why Indonesians concerned more about Palestinian instead of their fellow citizen in Surabaya cities who just bombed by terrorist on 14th-15th of May 2018(7 Tweets)

3. Suspecting that the Surabaya bombing was carried out by terrorists to divert public opinion from the inauguration of the US Embassy in Jerusalem (6 Tweet)

4. There were 3 Tweets mentioned @ Jokowi and asked the president to provide more assertive assistance to the Palestinians.

5. There were 2 accounts that defended Israel.

Of the 122 Tweets only 3 were from the Ministry of Foreign Affairs, namely @Menlu_RI, @kbriwina, dan @ riyadhkabri (Retweeted @Menlu_RI). @Menlu_RI tweeted these 5 sentences on 14th of May 2018:

1. Indonesia strongly condemns the United States' decision to open its Embassy in Jerusalem.

2. The decision of the United State has violated various United Nations Security Council and General Assembly Resolutions, as well as threatened the peace process and peace itself.

3. Indonesia urges the United Nations Security Council and the General Assembly to immediately convene in order to take firm position and action.

4. Indonesia calls on other UN member states not to follow the path of the United States.

5. The Government and the people of Indonesia will continue to stand with the Palestinians in fighting for their inalienable rights and independence.

The first tweet had relatively high response which is retweet 509 times and got 437 likes and 39 comments.

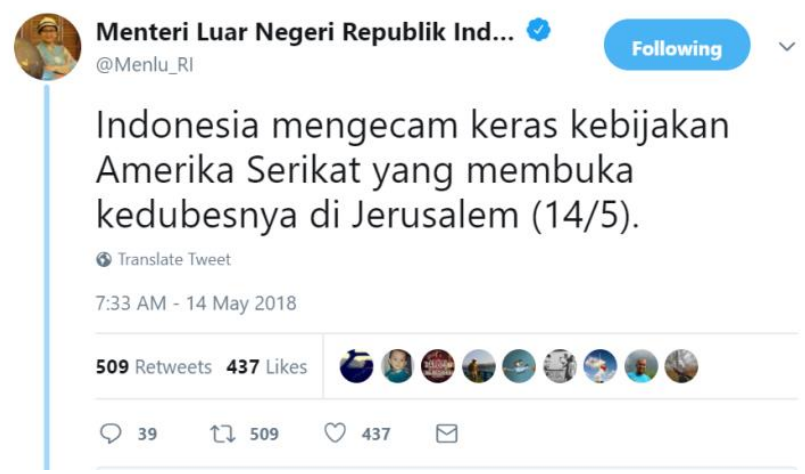

Figure 4.Indonesian Foreign Minister's Tweet.

On 15th of May, @Menlu_RI tweeted her diplomatic activity with a flat tone:

"Spoke with my good friend Turkish Foreign Minister MevlütÇavuşoğlu on the situation in Gaza We discussed the possibility for the OIC to hold an Extraordinary Summit on the situation in Gaza." 
The account of Indonesian Foreign Minister @ Menlu_RI was created on 5th of February 2018. Qualitative observation of all Tweets of @Menlu_RI on Palestinian issue from February until July 2018 discovered that most of the Tweets were information about what the Foreign Minister was doing or has done. For example:

17th of May 2018:

I attended the United Nations Forum in the Question of Palestine. My presence is to show the strong support of Indonesia to the Palestinian cause.

\section{1stof May 2018:}

- I met Foreign Minister Adel bin Ahmed Al Jubeir from Saudi Arabia on the sidelines of FM \# G20 meeting.

- Minister Adel and I also agree to continue to give our full support to the Palestinian people.

\section{1stof May 2018:}

- This morning, I chaired the MIKTA Foreign Ministers Meeting (Mexico, Indonesia, Korea, Turkey, Australia), in Buenos Aires (21/5). Indonesia is the current Chairman of MIKTA, under the theme "Fostering the Creative Economy and Contributing to Global Peace".

- In particular I also asked MIKTA countries not to open their embassies in Jerusalem.

\section{6th of June 2018:}

- I met my Palestinian Foreign Minister Riyad Maliki before the CEAPAD (Cooperation among East Asian Countries for Palestinian Development) conference in Bangkok (26/6).

- I reaffirm Indonesia's commitment to the Palestinian struggle and we will always be with the Palestinian people to gain independence. Palestine is one of the priority issues of Indonesia's membership in the UNSC.

Account@Menlu_RI only Tweeted two times which directly 'talking' to foreign government.

14th of May 2018 (as mentioned above)

26th of June 2018:

Indonesia jugaserukanseruanpolitikbaginegara yang memilikihubungandengan Israel untuktidakmemindahkankedutaannyake Jerusalem danbaginegara yang belummengakuiPalestinauntuksegeramelakukannya.

[Indonesia convey a political call for countries that have diplomatic relations with Israel not to move their embassy to Jerusalem and countries that have not yet recognized the Palestinians to do so soon.]

Another interesting point observed, on the 14th of June 2018 the Israeli Prime Minister @ Netanyahu tweeted: 
A special meeting today in Jerusalem with YahyaCholilStaquf, the General Secretary of the global Islamic organization NahdlatulUlama. I'm very happy to see that Arab countries and many Muslim countries are getting closer to Israel!

Since Mr. Yahya is a member of the Presidential Advisory Council, his trip to Jerusalem and his meeting with Netanyahu raised a harsh debate in social media. The public opinion was split between Mr. Yahya's defenders and his opponents. The opponents interpreted the visit as the sign that Mr. Joko Widodo administration is leaning towards Israel.

Both account@Jokowi or@Menlu_RI did not tweet any response to @ Netanyahu. But two days earlier the Indonesian Foreign Minister gave the response in the mass media, "That (Mr. Yahya'svisit to Israel) does not change Indonesia's position on Palestine. It does not change even an inch" [15].

Meanwhile, Ministry of Foreign Affairs account @Kemlu_RI only tweeted two times in 14th-15th of May 2018 sharing links to the official website of Ministry of Foreign Affairs:

- Indonesia's Response on the Opening of the US Embassy in Jerusalem https://t.co/Sr6J0JHLy8

- Indonesia Strongly Condemns the Killing of Palestinian Demonstrators by Israeli Soldiers https://t.co/DPpqkwckgfhttps://t.co/gpHs98IDua

At the same time, @ Jokowi did not tweet anything related to Palestinian issues.

We made a qualitative observation of the @ Kemlu_RI Tweets since the beginning of 2018 It appears this account only gives an announcement of what is done by the Ministry of Foreign Affairs and the Minister of Foreign Affairs. On 8th of January 2018 @Kemlu_RI Tweeted 120 times which contained a copy-paste of 'Annual Press Statement of the Minister of Foreign Affairs of the Republic of Indonesia 2018'. Several points of which are related to Palestine issue, as such:

- Sikap Indonesia mengenai Palestina, termasuk status Yerusalem, sudah sangat jelas, tegas dan konsisten, sesuai panggilan Konstitusi. Sikap yang konsisten ini juga disampaikan pada KTT Luar Biasa OKI di Istanbul, 13 Desember 2018.

- Palestina ada di jantung politik luar negeri Indonesia. Setiap helaan napas diplomasi Indonesia, di situ terdapat perjuangan untuk Palestina. Pada kesempatan yg baik ini, Indonesia kembali menyerukan kepada negara dunia agar terus memberikan dukungan bagi Palestina.

[Indonesia's position on Palestine, including the status of Jerusalem, is very clear, firm and consistent, as the Constitution calls it. This consistent attitude was also presented at the OIC's Overseas Summit in Istanbul, 13th of December 2018.

Palestine is in the heart of Indonesia's foreign policy. In every breath of Indonesian diplomacy, there is a struggle for Palestine. On this good occasion, Indonesia again called on the world countries to continue to provide support for the Palestinians.] 
On 22nd of July @Kemlu_RI responded the approval of Jewish Nation-State Law by the Israel's parliament with a quite hard language in Bahasa Indonesia (using the word mengutuk/condemn):

1. Indonesia mengecam pengesahan UU "Negara Bangsa Yahudi" (the Jewish NationState Law) oleh Parlemen Israel, Kamis, 19 Juli 2018.

2. Pengesahan UU ini menafikan hak-hak warga negara Israel keturunan Palestina dan mengancam penyelesaian konflik berdasarkan two-State solution.

[Indonesia condemned the passage of the ACT "State of the Jews" (the Jewish NationState Law) by Israel's Parliament, Thursday, 19th of July 2018.

The passage of this law denies the rights of citizens of Palestinian descent and Israel threatening conflict resolution based on the two-State solution.]

From this discussion, it appears that there are at least two things that need to be considered by the Ministry of Foreign Affairs of Indonesia:

1. The Indonesian government has not enhanced its power in diplomacy using the social media platform, especially Twitter, to influence the policies and attitudes of other governments in the issue of Palestine. The government's utilization of Twitter to speak directly to the Indonesian public on the issue of Palestine is still low. Public opinion on the Palestinian issue is still largely influenced by public accounts, including accounts that exploit this issue to discredit the government, or accounts that do not have a proper knowlegde on the issue (e.g. accounts that think there are Indonesian diplomats in Israel, or accounts who defends Israel). The small number of Tweets from the@Menlu_RI, @Kemlu_RI@Jokowi seems inconsistent with the Foreign Minister's claim, 'Palestine is in the heart of Indonesian foreign policy' and unbalanced by the large number of Tweets from the Indonesian public who are conserned over the Palestinian issue. The minimum Tweet means low exposure and minimal connection, so the back-door effort that has been done by the government so far in achieveing Palestinian independence does not resonate well in the society.

2. Indonesian government has not used the social media effectively in the framework of influencing the policies and attitudes of other governments. Most of tweets of @Menlu_RI, @Kemlu_RI are announcements or information of the government activities towards Palestine issue. Twitter actually gives an opportunity to the President or Foreign Minister to directly communicate with the President of USA or the Prime Minister of Israel and convey the country'sdemands on Palestine issue, but this has not been benefitted.

\section{CONCLUSION}

The emotional connection between Indonesia and Palestine has begun since the 1930s when both nations were still colonized by foreign power. After Indonesia proclaimed her independence on 17th of August 1945, the important figures of Arab countries, including Palestine, played a significant role in raising official recognition of Indonesia's independence and sovereignty. Since then,one of main focuses of Indonesia's foreign policy is achieving Palestinian independence. 
Alongside with the increasing use of social media as a tool of diplomacy by the world leaders, Indonesia has the opportunity to improve its power in conducting a pro-Palestinian ediplomacy. However, the observation of some important accounts related to Indonesia's foreign policy (@Menlu_RI, @Kemlu_RI, @Jokowi) found that the government has not used this opportunity effectively. Therefore, government of Indonesia should enhance the utilization of advanced technology such as twitter, instagram, and another social media platform in more effective way in the future.

\section{REFERENCES}

[1] Ihsanuddin, "Jokowi: Rakyat Indonesia Akan Berjuang Bersama Rakyat Palestina," Kompas, $2018 . \quad$ [Online]. Available: https://nasional.kompas.com/read/2018/05/11/10350191/jokowi-rakyat-indonesiaakan-berjuang-bersama-rakyat-palestina.

[2] I. Pappe, Pembersihan Etnis di Palestina. Jakarta: Elex Media Komputindo, 2006.

[3] S. A. Siroj and H. F. Zaini, "Kronik Kronologis Dokumen Komitmen PBNU atas Kemerdekaan Palestina," NU Online, 2018. .

[4] M. Z. Hassan, Revolusi Indonesia di Luar Negeri. Jakarta: Bulan Bintang, 1980.

[5] O. S. Adesina, "Foreign policy in an era of digital diplomacy," Cogent Soc. Sci., vol. 3, no. 1, pp. 1-13, Mar. 2017.

[6] S. Suryokusumo, Praktik Diplomasi. Jakarta: STIH "Iblam," 2004.

[7] Y. Tenembaum, "Diplomacy Is the Art of Enhancing Power," E-International Relations, 2017. [Online]. Available: https://www.e-ir.info/2017/02/22/diplomacy-isthe-art-of-enhancing-power/.

[8] E. Harder, "How Twitter Is Changing the Face of Foreign Policy," Mediashift, 2012. [Online]. Available: http://mediashift.org/2012/11/how-twitter-is-changing-the-faceof-foreign-policy319/.

[9] I. Manor, "Public Diplomacy and the Digital Society," in The Digitalization of Public Diplomacy, Cham: Springer International Publishing, 2019, pp. 29-63.

[10] Burson-Marsteller, "Twiplomacy Study 2013," Twiplomacy, 2013. [Online]. Available: https://twiplomacy.com/blog/twiplomacy-study-2013.

[11] W. Bolewski, Diplomacy and International Law in Globalized Relations. Heildelberg: Springer, 2007.

[12] C. Duncombe, "How Twitter is transforming diplomacy: Iranian tweets and the P5+1 nuclear negotiations," Medium, 2017. [Online]. Available: https://medium.com/international-affairs-blog/how-twitter-is-transforming-diplomacyiranian-tweets-and-the-p5-1-nuclear-negotiations-cc56bdcafac6.

[13] Burson-Marsteller, "Twiplomacy 2017 Full Study," Twiplomacy, 2017. .

[14] Antara News, "Palestina selalu di jantung politik luar negeri Indonesia, kata Menlu," Antara News, 2017. [Online]. Available: https://www.antaranews.com/berita/660996/palestina-selalu-di-jantung-politik-luarnegeri-indonesia-kata-menlu.

[15] F. J. Kuwado, "Yahya Staquf Bicara di Forum Israel, Menlu Jamin Sikap RI soal Palestina Tak Berubah," Kompas, 2018. [Online]. Available: https://nasional.kompas.com/read/2018/06/12/18275221/yahya-staquf-bicara-diforum-israel-menlu-jamin-sikap-ri-soal-palestina-tak. 